\title{
sciendo
}

DOI 10.2478/sbe-2020-0049

SBE no. 15(3) 2020

\section{EFFECTS OF COVID-19 ON BUSINESS MODELS IN ROMANIA AND THE NETHERLANDS, A DIGITALIZATION PERSPECTIVE}

\author{
TARTARIN THIERRY \\ Saxion University of Applied Sciences, Nederland \\ ȚICHINDELEAN MIHAI \\ Lucian Blaga University of Sibiu, Romania \\ HAAKER TIMBER \\ Saxion University of Applied Sciences, Nederland
}

\begin{abstract}
:
The research objective is to study how Romanian and Dutch organizations' business models have changed under COVID-19 conditions. The role of digitalization in adapting business models and business practices is studied. The theoretical background reviews literature about business models and their dimensions. Literature review investigated digitalization in Romanian and Dutch organizations.

Research questions were:

To what extent do Romanian and Dutch organizations use:

- more digital methods in their offer to their clients now than before the crisis?

- more digital methods in their business processes now than before the crisis?

- more digital methods in communicating with their clients now than before the crisis?

To what extent are there any significant differences between Romanian and Dutch organizations regarding the use of digital methods?

Using qualitative and quantitative methods, conclusions show that Romanian and Dutch organizations adapted their business models to the ongoing COVID-19 crisis by applying digitalization in their value creation and value delivery using different digital methods. The frequency and choice of specific digital methods are in line with digitalization levels of Romania and The Netherlands as per the DESI index. In both countries, digitalization helped business models resilience although the level of digitalization in the organization's country were significantly different.
\end{abstract}

Keywords: business models; digitalization; COVID-19; business model innovation.

\section{Introduction}

\section{Practical relevance}


March 2020 saw the outbreak of the deadly COVID-19 virus which originated from China. This would affect the entire planet with unprecedented economical and human consequences. The highly infectious virus spread from individual to individual, country to country to finally be declared a pandemic (World Health Organization, 2020). As a result, countries started to impose lockdowns whereby people were forced to stay at home in order to lessen the speed of the viral dissemination and contain the overflow of patients in hospitals.

The consequences of the lockdown meant that worldwide manufacturing, supply of goods and spare parts have been abruptly ceased or severely interrupted, thus cutting down the lines of activities which would normally be necessary for any economy to operate in an effective manner.

As industries all over the world struggled to find ways to cope with this uniquely unfamiliar business context, new business models emerged, relying on shorter supply-chains or alternative ways to reach and communicate with the client. Organizations had to evaluate how to best adapt their supply-chain in order to carry on delivering products and services to their clients. Country policies, whose main purpose is to fight against the disease differed per country depending on the evaluation of the disease potency for people and their economy. The two main perspectives taken into account by politicians and country leaders have primarily focused on the damage to individuals versus the damage to an economy within a given time frame. The study of business models and digitalization of the organization's processes, communication and offer to the client is relevant and interesting as it may provide a practical insight into possible solutions to reduce the damage inflicted by COVID-19 to organizations and industries at large.

\section{Theoretical relevance}

The theoretical relevance of the research lies within the connection between the existing framework of the Digital Economy and Society Index (DESI) (European Commission, 2020) with its five key dimensions (connectivity, human capital, use of internet services, integration of digital technology and digital public services) and a key aspect, common to large variety of theories on business model innovation: the concept of digitalization. Through the cross referencing of two of the five DESI dimensions (connectivity and integration of digital technology) together with digitalization tools, i.e. communication platforms and finding relevant COVID-19 literature we were able to triangulate data and find new perspectives of the digital effects on business models in Romania and The Netherlands under COVID-19 conditions.

\section{Field of research}

The research is contributing to ongoing COVID-19 related academic research in the field of new business models and digitalization of organization's processes. The comparison between two countries with such extreme differences in terms of digitalization (The Netherlands being in the top five digitalized countries in Europe and Romania being in the bottom five) is used here to evaluate the resilience of business 
processes under COVID-19. The research will establish if there is a correlation between the countries' digital development and their capacity to adapt their business models under COVID-19 conditions.

\section{Research objective and research questions}

The research objective is to understand to what extent Romanian and Dutch organizations' business models have changed due to the present COVID-19 crisis. Business models are described as having four interrelated value dimensions, i.e. value proposition, value delivery, value creation and value capture (Lüdeke-Freund et al., 2019). To study the changes in business models, two value dimensions have been selected, i.e. value creation, value delivery. Sub dimensions relate to offer to the client, communication with the client and organization processes. Four research questions have been designed.

Research questions are as follows:

(1) To what extent do Romanian and/or Dutch organizations use more digital methods in their offer to their clients now than before the crisis?

(2) To what extent do Romanian and/or Dutch organizations use more digital methods in their business processes now than before the crisis?

(3) To what extent do Romanian and/or Dutch organizations use more digital methods in communicating with their clients now than before the crisis?

(4) To what extent are there any significant differences between Romanian and Dutch organizations regarding the use of digital methods?

\section{Contribution}

This paper contributes to the body of knowledge by giving an insight into how digitalization, as a business model innovation driver, has been instrumental in enabling organizations to maintain their activities in a COVID-19 restricted business environment. It also highlights how the existing level of digitalization in a country influences how companies in that country apply digitalization in response to the COVID-19 crisis. Our findings support the suggestion that organizations in countries with different levels of digitalization development were equally able to adapt their business models by adapting their digital applications to the new business conditions.

\section{Structure}

The paper is structured as follows: in the introduction the context of the research is described in relation to the impact of COVID-19 to organizations worldwide as well as the reasoning

of the research related to business models and digitalization. Consequently, the theoretical background is described and followed by the research design where the methodology and reliability are discussed. Next, the results are presented of the quantitative and qualitative data collected. A discussion and conclusion complete the research paper leading to suggestions for future research. 


\section{Theoretical background}

Business models can be defined as a concept which encapsulates the creation and capture of a number of values meant to satisfy stakeholders (Bouwman, De Vos, \& Haaker, Mobile service innovation and business models, 2008) (Chesbrough \& Rosenbloom, 2002) (Linder \& Cantrell, 2000) (Osterwalder \& Pigneur, 2010) (Lüdeke-Freund, Gold, \& Bocken, 2019).

Business models provide an effective tool to evaluate and monitor business options especially in fast changing environments (McGrath, 2010). A well-known descriptive model and tool is the Business Model Canvas (Osterwalder \& Pigneur, 2010) with a focus on a focal firm providing some offering and value proposition. Others have different approaches like the STOF model (De Vos \& Haaker, 2008) taking the product or service offering as the focal point or VISOR (El-Sawy \& Pereira, 2013) which is specifically apt when considering a digital offering. A common denominator of existing business models design methodology is the relation to the value dimensions and variables as for example Lüdeke-Freund framework (Lüdeke-Freund, Gold, \& Bocken, 2019) of value proposition (product and service), value delivery (target customer and delivery processes), value creation (partners, stakeholders, value creation processes), and value capture (revenue and costs).

Values from a marketing perspective are linked to the satisfaction of the client in terms of wishes, wants and demands (Kotler, P; Armstrong, G, 2015) (Kotler, P; Kartajaya, H; Setiawan, I, 2019). More and more consumers seek experiences and not possessions for satisfying their needs (Chun, H. H., Diehl, K., \& Maclnnis, D. J.,2017), these experiences are being sought nowadays at home in a safe environment. Therefore, in a "new normal" context whereby COVID-19 remains a threat to effective communication with the client, organizations should consider virtual and/or augmented reality, video conferencing and online distribution options (Kirk \& Rifkin, 2020).

Digitalization defined as a combination of different digital technologies leading to better performances (Vorraber, Gundhille, Rachinger, Rauter, \& Eva, 2017) plays nowadays an important role in business and in particular business model innovation (Rachinger, Rauter, Muller, Vorrader, \& Schirgi, 2019). Business model innovation can be defined as "a change in a company's business model that is new to the firm and results in observable changes in practices towards customers and partners (Bouwman, de Reuver, \& Shahrokh, 2017). As client's wishes, wants and demands evolve over time there is a need for innovation in order to keep satisfying them. Digitalization helps not only to achieve better performances but also supports business model innovation through better fulfillment of values to the client. Other drivers for digitalization in business model innovation include achieving cost benefits.

Therefore, it can be argued that innovation is a key driver of business models with digitalization a supporting element (De Reuver, Bouwman, \& MacInnes, 2009).

Digital performance in Europe is tracked amongst European member states through the Digital Economy and Society Index (DESI). DESI uses five key indicators 
to evaluate digital competitiveness with different calculation weights: Connectivity (25\%), Human capital (25\%), Use of internet services (15\%), Integration of digital technology (20\%) and Digital public services (15\%). Each indicator(dimension) is then using sub dimensions as follows:

Table 1. List of Dimensions and sub dimensions, Digital Economic and Society Index

\begin{tabular}{ll}
\hline DESI dimensions (indicators) & Sub dimensions \\
\hline Connectivity & Fixed broadband take-up \\
& Fixed broadband coverage \\
& Mobile broadband \\
& Broadband price index \\
\hline Human capital & Internet user skills \\
& Advanced skills and development \\
\hline Use of internet services & Internet use \\
& Activities online \\
\hline Integration of digital technology & Transactions \\
\hline Digital public services & Business digitization \\
\hline
\end{tabular}

Source: European Commission, 2020

When all indicators are aggregated The Netherlands ranks $4^{\text {th }}$ compared with Romania which ranks $26^{\text {th }}$ out of 28 EU members.

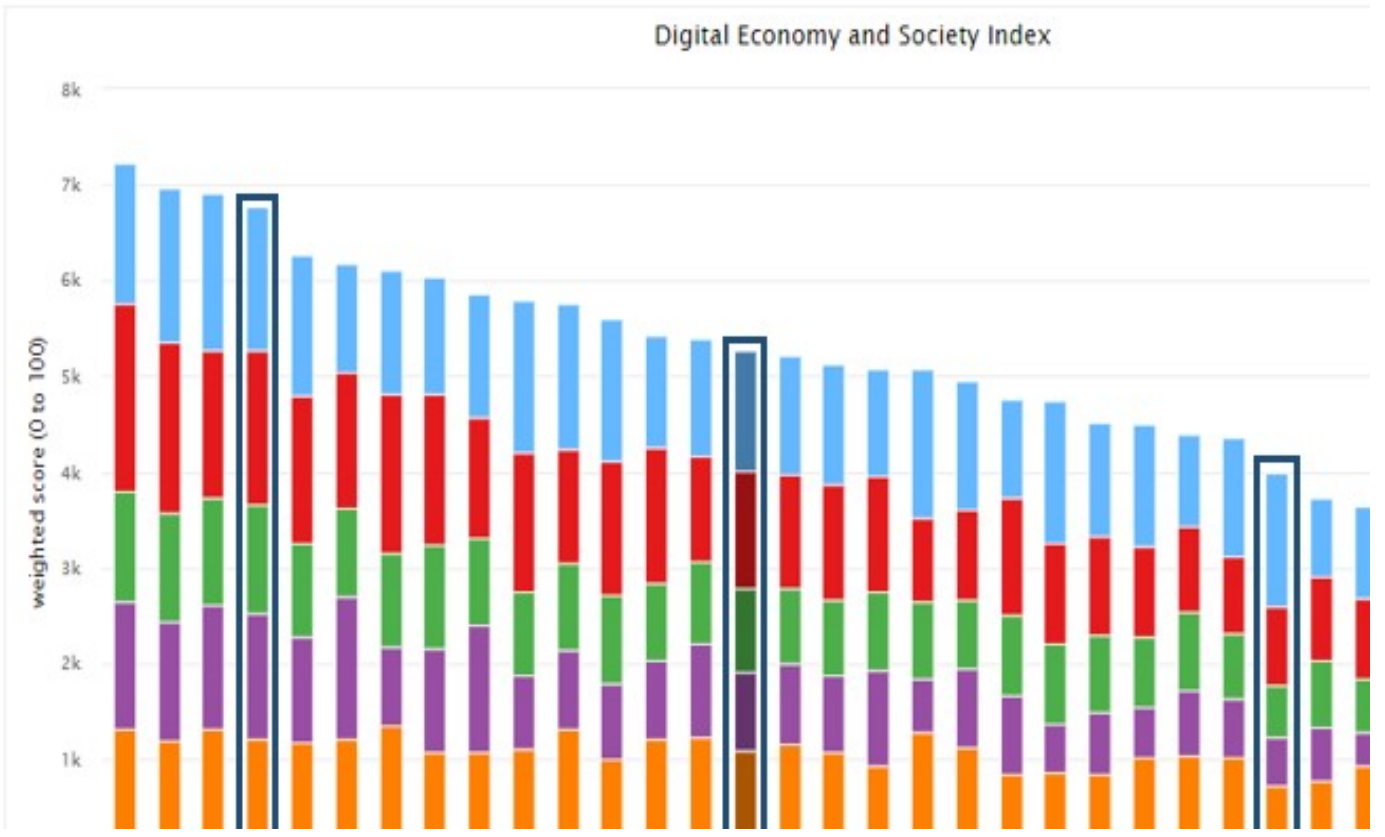

Fig. 1. Comparison of digitalization amongst EU members (all indicators)

Source: European Commission, 2020 
Although from a total digitalization perspective Romania lacks far behind being ranked amongst the bottom five whilst The Netherlands is in the top five, further examination of the indicators gives a different picture.

Connectivity for instance is ranked $11^{\text {th }}$ for Romania well ahead of countries such as France or The United Kingdom.

1 Connectivity, by Sub-dimensions of 1 Connectivity

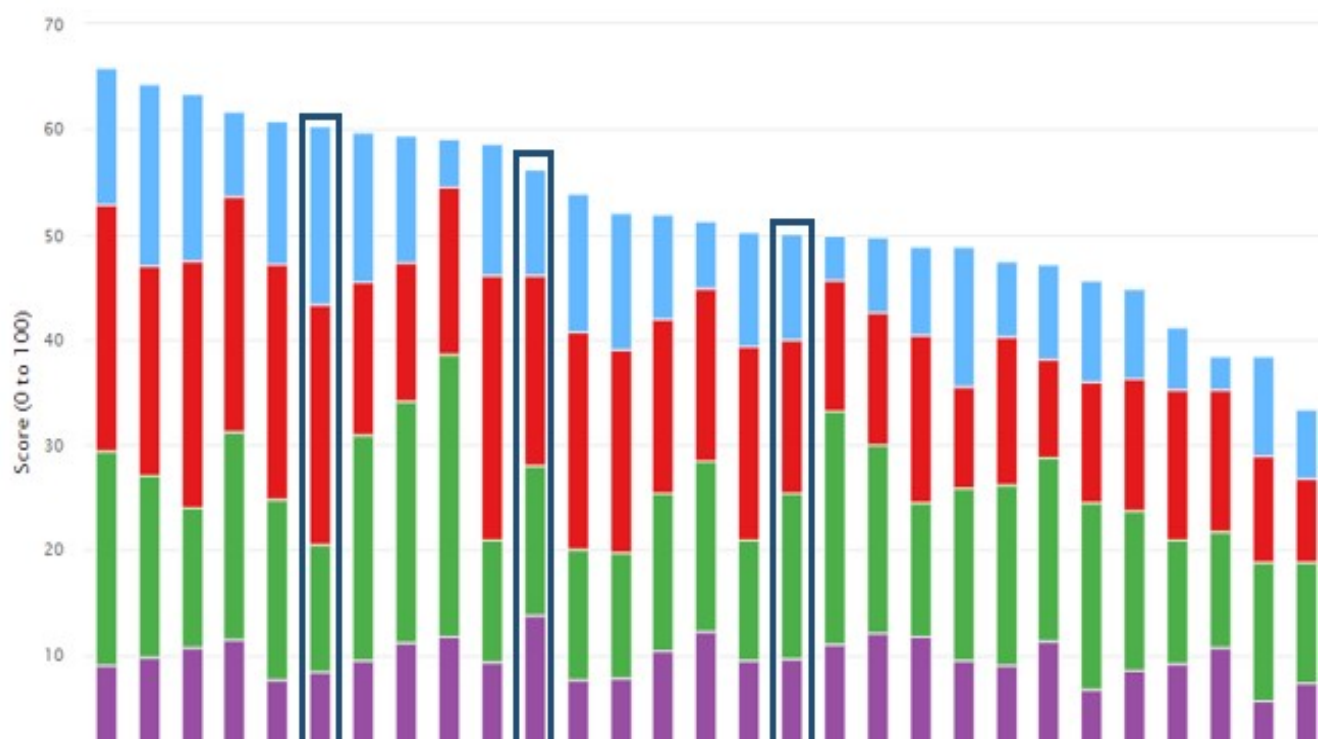

Fig. 2. Comparison of digitalization amongst EU members, indicator: Connectivity

Source: European Commission, 2020

This can be explained by the fast development of fixed broadband connections in a country which did not have a developed digital infrastructure to start with. " $49 \%$ of Romanian homes subscribe to ultrafast (at least $100 \mathrm{Mpbs}$ ) broadband, the fifth highest figure in the EU" (European Commission, 2020) and well ahead of The Netherlands. 5G readiness The Netherlands scores low with $0 \%, 5 G$ spectrum assigned while Romania scores $21 \%$ similar to the EU average (The $5 \mathrm{G}$ spectrum readiness indicator is based on the amount of spectrum already assigned and available for $5 \mathrm{G}$ use by 2020 within the $5 \mathrm{G}$ pioneer bands in each EU Member State). 
la Fixed broadband take-up, by la2 At least 100 Mbps fixed BB take-up

EU

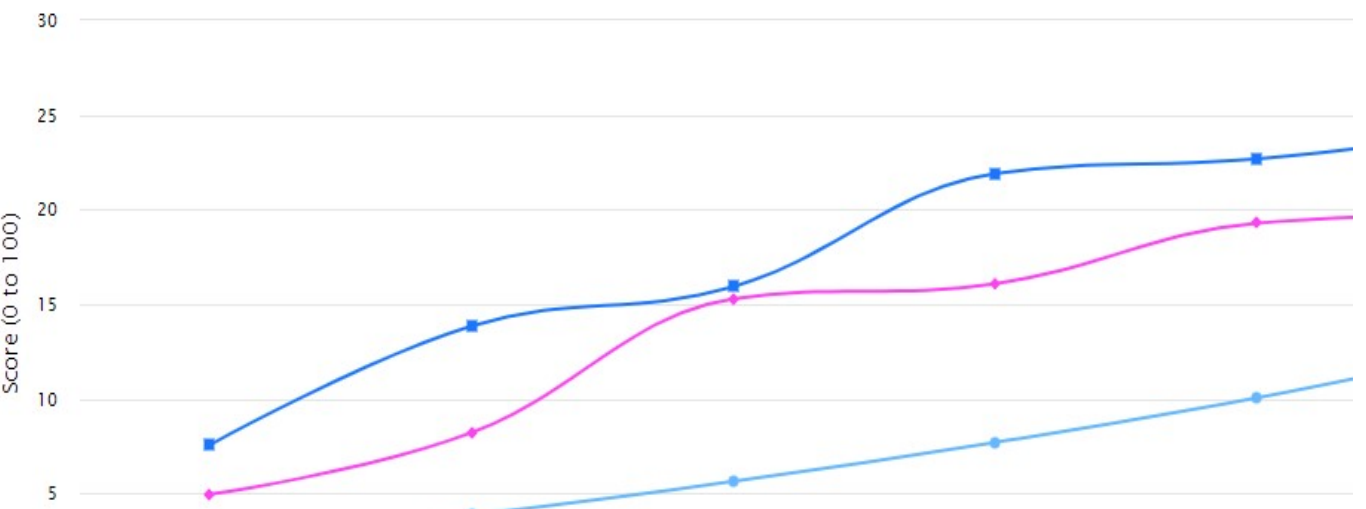

Fig. 3. Comparison of fixed broadband take-up, connectivity indicator (Romania,

The Netherlands), period 2015 - 2020

Source: European Commission, 2020

E-commerce within the digital technology dimension sees a significant development in COVID-19 year 2020 compared to previous years.

4 Integration of Digital Technology, by $4 \mathrm{~b}$ e-Commerce

EU

25

20

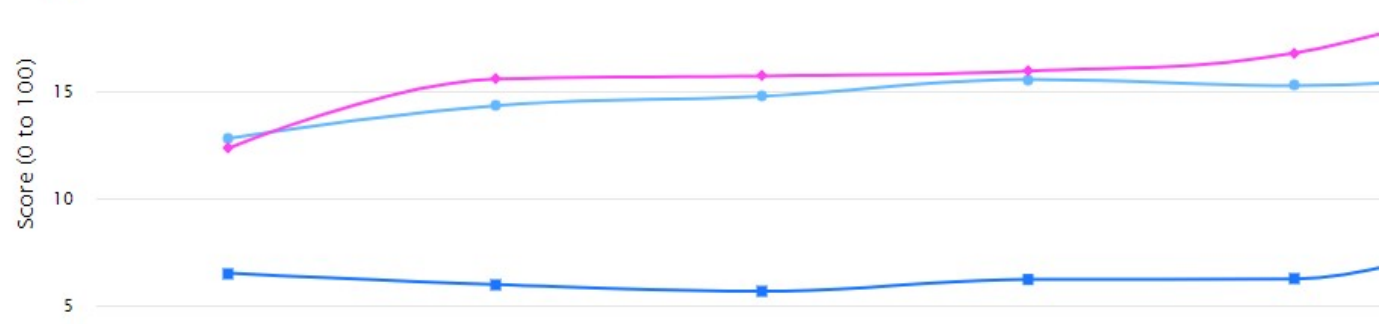

Fig. 4. Comparison of integration of Digital technology (Romania, The Netherlands), period 2015 - 2020

Source: European Commission, 2020

As COVID-19 interrupted the normal running of existing business models (OECD, 2020), business model innovation was needed to resist the negative effects of the pandemic by redesigning business models as an emergency measure to safeguard the effective presence of the organization in its market (OECD, 2020).

Digital areas affected under COVID-19 were amongst others linked to the offer and communication to the client. This occurred due to the fact that the client was, for 
instance unable to be physically present in the office or in a shop nor was he able to see billboards in the street.

Business processes benefited from a near instantaneous switch to digital services, such as the ones encountered in the educational sectors within all high income countries where physical classes switched to the video conferencing capacity of their digital platform such as Blackboard or Natschool in The Netherlands or Google education in Romania (World Bank, 2020).

\section{Research Design}

In order to achieve the research objective, a descriptive, simple cross-sectional research was chosen. Survey was used as a research method and questionnaire as a data collecting instrument. The questionnaire contained 26 questions (three multiple choice, six closed questions, five open-end questions and 12 five-point Likert scale questions) which resulted in both quantitative and qualitative data. The questionnaire was written in the Romanian and Dutch languages and distributed online by using the Qualtrics platform. Data was collected between the months of April and July 2020 from individuals which were representatives (entrepreneurs or employees) of profit or nonprofit-oriented organizations. Thus, the information source is an external one, organization related, a primary and free information source.

The initial sample size was $n=453$; after editing the data, 320 individual responses were considered valid and used for analysis. In regard to the organization's country, orientation, and number of employees as criteria, the used sample has the following structure:

Table 2. Distribution of the organizations according to their country origin

\begin{tabular}{lll}
\hline Origin & Absolute values & Percentage \\
\hline Dutch & 194 & $60.6 \%$ \\
\hline Romanian & 126 & $39.4 \%$ \\
\hline Total & 320 & $100 \%$ \\
\hline \multicolumn{2}{c}{ Source: own computation }
\end{tabular}

194 Dutch and 126 Romanian organizations were analyzed, most of them being profit-oriented (251/78.44\%) and large employers (143/44.7\% have over 250 employees). For answering all the proposed research questions, the authors have analyzed both quantitative and qualitative data. In this regard, descriptive statistics were applied and Chi-square and post-hoc tests were performed to check the statistical difference between the used categorical variables. Moreover, based on a set of predefined codes, the three authors blind-coded the qualitative data using open coding; an agreement rate of over $70 \%$ was considered reliable for validating the predefined codes. 


\section{Results}

Since the beginning of the COVID-19 crisis in Europe, social and business interactions have been affected. A number of new business work practices such as working from home and extensive use of video conferencing tools have developed as a consequence of the physical impossibility to meet face to face and travel to conduct business with clients and other stakeholders. Organizations have in the main seized this threat to their business by turning it into a possible opportunity by means of extending their existing digital offer or by creating of a new digital offering (e.g. web shops, digital entertainment, digital communication platforms). The central objective was to try to limit the damage this situation created for their business model. In Table 3, a cross-tabulation is performed of how many Dutch and Romanian organizations have changed their operations in response to the corona crisis:

Table 3. Cross-tabulation between change in the organizations' operations due to the corona crisis and their country origin

\begin{tabular}{|c|c|c|c|c|c|}
\hline \multirow{2}{*}{ Question } & \multirow{2}{*}{ Answer } & \multirow{2}{*}{ Indicators } & \multicolumn{2}{|c|}{ Country origin } & \multirow{2}{*}{ Total } \\
\hline & & & $\mathrm{NL}$ & $\mathrm{RO}$ & \\
\hline \multirow{4}{*}{$\begin{array}{l}\text { Providing your organization is currently } \\
\text { open for business, have you so far changed } \\
\text { any of your operations in response to the } \\
\text { Corona crisis? }\end{array}$} & \multirow{4}{*}{ Yes } & Count & 171 & 86 & 257 \\
\hline & & $\%$ within Answer & $66.5 \%$ & $33.5 \%$ & $100 \%$ \\
\hline & & $\%$ Country origin & $88.1 \%$ & $68.3 \%$ & $80.3 \%$ \\
\hline & & Adjusted Residual & 4.4 & -4.4 & \\
\hline
\end{tabular}

Both Dutch $(88.1 \%)$ and Romanian $(68.3 \%)$ organizations have changed their operations in response to the corona crisis. Based on the Chi-square (19.11) and posthoc tests ( $p$-value $<0.01$ for every adjusted residual), it can be stated that more Dutch organizations have changed their operations than Romanian ones.

Research question 1 (RQ1) - To what extent Romanian and/or Dutch organizations use more digital methods in their offer to their clients now than before the crisis?

A two-step analysis is performed for answering research question 1. Firstly, a cross-tabulation is carried out between the organizations' country of origin and their usage (or not) of more digital methods in their offer to clients because of the corona crisis.

Table 4. Cross-tabulation between change in the organizations' use of more digital methods in their offer to clients due to the corona crisis and their country origin

\begin{tabular}{|c|c|c|c|c|c|}
\hline \multirow{2}{*}{ Question } & \multirow{2}{*}{ Answer } & \multirow{2}{*}{ Indicators } & \multicolumn{2}{|c|}{ Country origin } & \multirow{2}{*}{ Total } \\
\hline & & & $\mathrm{NL}$ & $\mathrm{RO}$ & \\
\hline \multirow{4}{*}{$\begin{array}{l}\text { In my offer to clients, I now use more digital } \\
\text { methods than before the crisis? }\end{array}$} & \multirow{4}{*}{ Yes } & Count & 140 & 44 & 184 \\
\hline & & $\%$ within Answer & $76.1 \%$ & $23.9 \%$ & $100 \%$ \\
\hline & & $\%$ Country origin & $72.2 \%$ & $34.9 \%$ & $57.5 \%$ \\
\hline & & Adjusted Residual & 6.6 & -6.6 & \\
\hline \multicolumn{6}{|l|}{ Source: own computation } \\
\hline \multicolumn{6}{|c|}{ - 123 - } \\
\hline
\end{tabular}


First of all, Table 4 values indicate that more Dutch organizations $(72.2 \%)$ have used more digital methods in their offering to their clients than those who have not $(27.8 \%)$. On the other hand, more Romanian organizations $(65.1 \%)$ have not used more digital methods in their offering to their clients than those who have $(34.9 \%)$. These ideas are statistically validated by the Chi-square test values $\left(\chi^{2}=43.36, p\right.$-value $\left.<0.01\right)$ and post-hoc test values ( $p$-value $<0.01$ for every adjusted residual).

Secondly, open-end answers were analyzed by using specific qualitative data analysis techniques. Thus, those respondents who have agreed that their organization has used more digital methods in their offering to clients since the corona crisis, were asked to write down those used digital methods. The 131 valid text fragments considered for the qualitative analysis were assigned by each author to one or more of the following predefined codes: digital learning, digital documents, digital conferences, improved digital communication, digital translation, increased business, increased digital advertising, and internal operations fully digital. Large text fragments have contained information which were proper to more than one predefined code, thus more codes could have associated to one answer. An agreement rate between the authors of over $70 \%$ was obtained for every predefined code, thus the codes were validated.

In order to check for differences between Romanian and Dutch organizations regarding the use of digital methods (RQ1) in their offer to clients, Chi-square and post-hoc tests were performed. One assumption for performing the chi-square test is that the expected frequencies should be over 5 ; for larger samples, the percentage of expected frequencies under 5 should be under $20 \%$ and none of it under 1 (Field, 2009). In our case, out of 16 (8 codes $\times 2$ countries) expected frequencies $11(68.75 \%)$ exceed this value. To validate this assumption, we have step-wise eliminated those digital methods (codes) with the least expected frequencies. The following table contains the digital methods which respect the upper mentioned assumption; thus, the chi-square test can be performed without losing any statistical power.

Table 5. Cross-tabulation between the organizations' used digital methods in their offer to their clients and their country of origin

\begin{tabular}{|c|c|c|c|c|}
\hline \multirow{2}{*}{ Codes } & \multirow{2}{*}{ Indicators } & \multicolumn{2}{|c|}{ Country origin } & \multirow{2}{*}{ Total } \\
\hline & & $\mathrm{NL}$ & $\mathrm{RO}$ & \\
\hline \multirow{3}{*}{ Digital learning } & Count & 21 & 0 & 21 \\
\hline & Expected count & 17.3 & 3.7 & 21 \\
\hline & Adjusted residual & 2.3 & -2.3 & \\
\hline \multirow{3}{*}{ Improved digital communication } & Count & 58 & 22 & 80 \\
\hline & Expected count & 66 & 14 & 80 \\
\hline & Adjusted residual & -3.7 & 3.7 & \\
\hline \multirow{3}{*}{ Internal operations fully digital } & Count & 29 & 1 & 30 \\
\hline & Expected count & 24.7 & 5.3 & 30 \\
\hline & Adjusted residual & 2.3 & -2.3 & \\
\hline
\end{tabular}

Source: own computation

In a descriptive manner, we can observe that more Dutch than Romanian organizations use in their offer to their clients more digital methods specific for digital learning, for improving their digital communication, and for fully digitalizing their 
operations. Statistically, we can state that more Dutch organizations and less Romanian ones improved their digital communication in their offer to clients since the corona crisis $\left(\chi^{2}=14.13\right.$ and $p$-value $<0.01$ for improved digital communication adjusted residuals).

Research question 2 (RQ2) - To what extent Romanian and/or Dutch organizations use more digital methods in their business processes now than before the crisis?

The same two-step analysis as for RQ1 was performed for analyzing RQ2. Thus, most organizations $(67.2 \%)$ use more digital methods in their business processes now than before the crisis. In addition, more Dutch organizations (76.3\%) than Romanian ones $(53.2 \%)$ have increased the usage of digital methods in their processes as a response to the corona crisis (Table 6). According to the Chi-square and post-hoc tests $\left(\chi^{2}=18.51\right.$ and p-value $<0.01$ for all adjusted residuals), the previous statement has also statistical relevance.

Table 6. Cross-tabulation between the organizations' usage of more digital methods in their processes as response to the corona crisis and their country origin.

\begin{tabular}{|c|c|c|c|c|c|}
\hline \multirow{2}{*}{ Question } & \multirow{2}{*}{ Answer } & \multirow{2}{*}{ Indicators } & \multicolumn{2}{|c|}{ Country origin } & \multirow{2}{*}{ Total } \\
\hline & & & NL & $\mathrm{RO}$ & \\
\hline \multirow{4}{*}{$\begin{array}{l}\text { Related to the organization's processes, I } \\
\text { now use more digital methods than before } \\
\text { the crisis. }\end{array}$} & \multirow{4}{*}{ Yes } & Count & 148 & 67 & 215 \\
\hline & & $\%$ within Answer & $68.8 \%$ & $31.2 \%$ & $100 \%$ \\
\hline & & $\%$ Country origin & $76.3 \%$ & $53.2 \%$ & $67.2 \%$ \\
\hline & & Adjusted Residual & 4.3 & -4.3 & \\
\hline
\end{tabular}

Source: own computation

Out of 215 positive responses, 161 detailed what types of digital methods they have used in their business processes as response to the corona crisis (RQ2). These responses were assigned with at least one of the following open-codes: communication platform, workplace platform, social media platform, and telephone. Cross-check of the codes was performed by the authors resulting in accepting all the codes (overlapping of the codes exceeded $70 \%$ for the considered texts). Because of the statistical restrictions (see $\mathrm{RQ1}$ ), only two codes were considered for further analysis: workplace platform, and communication platform, respectively.

Table 7. Cross-tabulation between the organizations' use of more digital methods (communication and workplace platforms) in their business processes in response to the corona crisis and their country origin.

\begin{tabular}{|c|c|c|c|c|}
\hline \multirow{2}{*}{ Codes } & \multirow{2}{*}{ Indicators } & \multicolumn{2}{|c|}{ Country origin } & \multirow{2}{*}{ Tota } \\
\hline & & $\mathrm{NL}$ & $\mathrm{RO}$ & \\
\hline \multirow{2}{*}{ Communication platform } & Count & 41 & 19 & 60 \\
\hline & Adjusted residual & -2.3 & 2.3 & \\
\hline \multirow{2}{*}{ Workplace platform } & Count & 76 & 14 & 90 \\
\hline & Adjusted residual & 2.3 & -2.3 & \\
\hline
\end{tabular}

Source: own computation 
Most of the organizations $(60 \%)$ used more workplace platform in their business processes in response to the corona crisis, while $40 \%$ of them increased their communication platform usage. Moreover, more Dutch organizations and less Romanian ones use more workplace platforms in their business processes as response to the corona crisis. Furthermore, less Dutch organizations and more Romanian ones use more communication platforms in their business processes as response to the corona crisis to adapt to the corona crisis' effects ( $\chi^{2}=4.45$ and $p$-value $<0.01$ for all adjusted residuals).

Research Question 3 (RQ3) - To what extent Romanian and/or Dutch organizations use more digital methods in communicating with their clients now than before the crisis?

About $64 \%$ of the analyzed organizations use more digital methods in contacting their clients now than before the corona crisis. Considering their country of origin, more Dutch than Romanian organizations use more digital methods for contacting their clients now than before the corona crisis. Furthermore, most Romanian organizations $(57.1 \%)$ do not use more digital methods in contacting their clients because of the corona crisis $\left(\chi^{2}=40.59\right.$ and $p$-value $<0.01$ for all adjusted residuals).

Table 8. Cross-tabulation between the organizations' use of more digital methods in contacting their clients in response to the corona crisis and their country origin.

\begin{tabular}{|c|c|c|c|c|c|}
\hline \multirow{2}{*}{ Question } & \multirow{2}{*}{ Answer } & \multirow{2}{*}{ Indicators } & \multicolumn{2}{|c|}{ Country origin } & \multirow{2}{*}{ Total } \\
\hline & & & $\mathrm{NL}$ & RO & \\
\hline \multirow{4}{*}{$\begin{array}{l}\text { In my contact with clients, I now use more } \\
\text { digital methods than before the crisis. }\end{array}$} & \multirow{4}{*}{ Yes } & Count & 151 & 54 & 205 \\
\hline & & $\%$ within Answer & $73.7 \%$ & $26.3 \%$ & $100 \%$ \\
\hline & & $\%$ Country origin & $77.8 \%$ & $42.9 \%$ & $64.1 \%$ \\
\hline & & Adjusted Residual & 6.4 & -6.4 & \\
\hline
\end{tabular}

Source: own computation

Detailed answers about what digital methods have been used in contacting the organizations' clients were provided by 156 respondents (RQ3). To these answers, at least one of the following open-codes were assigned: communication platform, webinar, social media platforms, workplace platforms, telephone, digital documentation, e-mail, and remote customer service. Cross-checking of the codes was performed by considering a $70 \%$ inter reliability threshold. Because of statistical reasons, Chi-square and post-hoc tests were performed for only three of the mentioned codes: communication platform, webinar, and workplace platform. Based on the results $\left(\chi^{2}=4.1\right.$ and $p$-value $\left.=0.128>0.05\right)$, we can assert that there is no statistical difference between Dutch and Romanian organizations in their usage of communication platforms, workplace platforms and webinars as digital methods in contacting their clients. 


\section{Discussion and conclusion}

The research objective of this paper is to understand to what extent Romanian and Dutch organizations' business models have changed due to the ongoing COVID19 crisis. To achieve this objective, the authors have studied if and how digitalization (as a driver for business model innovation) was used by Romanian and Dutch organizations in their value creation and delivery under COVID-19 conditions.

A first result shows that the majority of Dutch organizations $(72.2 \%)$ have used more digital methods in their offer to their clients in response to the COVID-19 crisis. In contrast a minority of Romanian organizations (34.9\%) have used more digital methods in their offer to clients in adapting to the COVID-19 conditions. These results are in line with the DESI reports for the two countries in that both countries' organizations have applied digital methods in their offer to clients relative to their different digitalization degree. Fig.5 below shows an increase from Romania, The Netherlands and the average EU about internet use.

3 Use of Internet Services, by 3a Internet use

EU

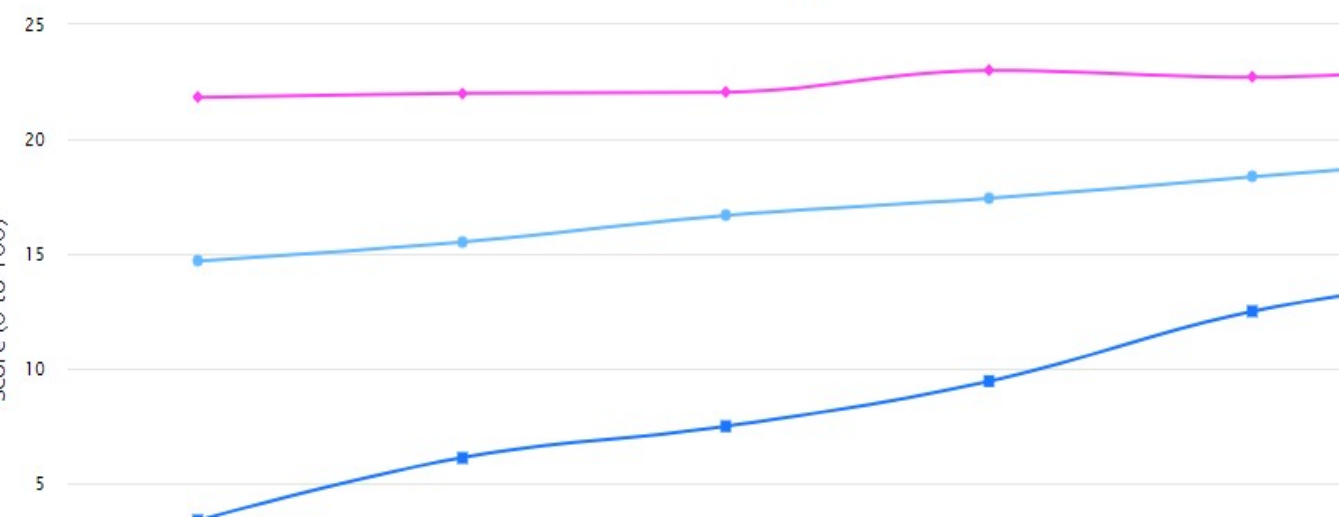

Fig. 5. Comparison use of internet services, Internet use (Romania, The Netherlands), period 2015 - 2020

Source: European Commission, 2020

After interpreting the qualitative data related to which particular digital methods were used by the organizations in their offer to clients, the authors found out that many answers were related to the increase of the organization's offer by digital means (e.g. using a website for managing orders, take-away alternative of products). These insights can be linked to a recent study in Romania (Butu, et al., 2020) which indicates a switch to digital methods for ordering local fresh vegetables. We find some evidence of this in the DESI report related to e-commerce for instance where both Romania and The Netherlands make comparable increase in their e-commerce activities, selling online from March 2020 onwards. 


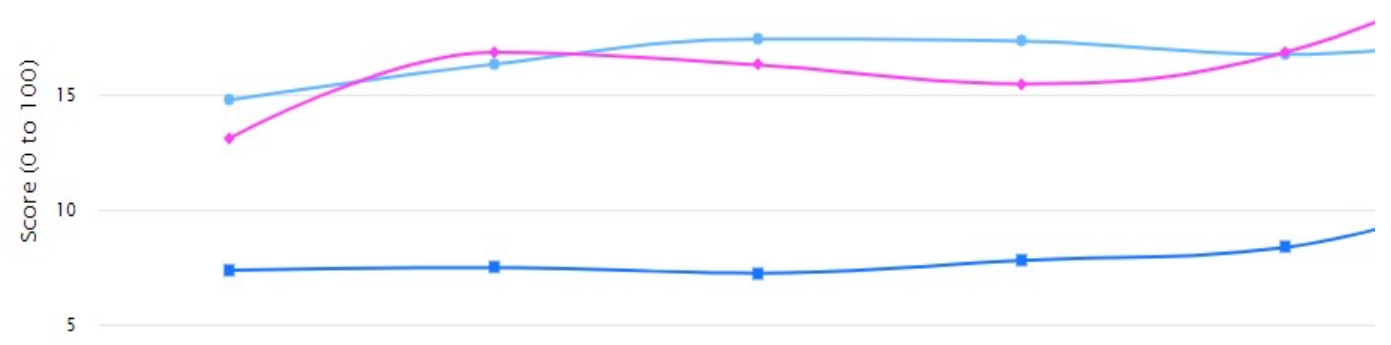

Fig. 6. Comparison e-Commerce, SME's Selling online (Romania, The Netherlands), period 2015 - 2020

Source: European Commission, 2020

e-Commerce, Selling online cross border in Romania sees a very significant increase pre-COVID-19 which is highly accentuated from March 2020 onwards.

4b e-Commerce, by 4 b3 Selling online cross-border

EU

20

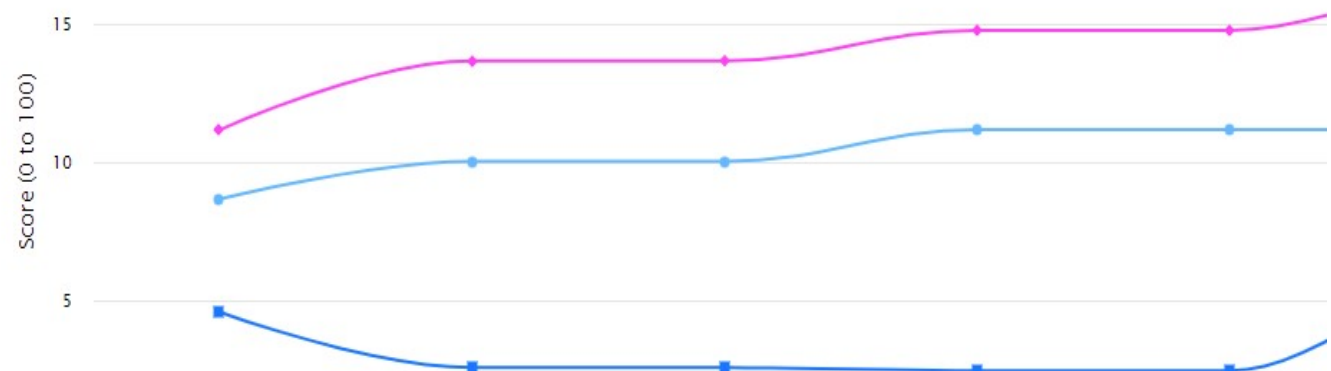

Fig. 7. Comparison e-Commerce, Selling online (Romania, The Netherlands), period $2015-2020$

Source: European Commission, 2020

In The Netherlands the impact of the lockdown also had a significant impact on consumer behaviour and as a result a majority of Dutch adults switched to an online environment to order food products (Poelman, et al., 2020).

A second result reveals that more Dutch organizations (76.3\%) than Romanian ones $(53.2 \%)$ use more digital methods in their business processes. These digital methods include both communication and workplace platforms, social media platforms, 
telephone, and VPN-services (to access the organizations' internal system remotely). Working from home is recommended to flatten the new COVID-19 infections curve, thus COVID-19 related public actions (e.g. lockdown, quarantine) act as facilitators for digital work (Richter, A., 2020), but it comes along with several challenges for organizations. These challenges relate to work productivity (Carnevale \& Hatak, 2020) which depends on the organizations' digital maturity and employee skills and mind-set. Although the digitalization of the organizations' processes is ongoing, setting up the infrastructure is not enough, trainings are necessary to develop the employees' digital skills and mind-set. As the organization's activities slowed down meaning less need for staff, another challenge was to identify key-workers to carry on business processes (Fletcher, G., Griffiths, M., 2020).

A third research result shows that most of the Dutch organizations $(77.8 \%)$ use more digital methods in contacting their clients now than before the COVID-19 crisis. On the contrary, most of the analysed Romanian organizations $(57.1 \%)$ have not used more digital methods in contacting their clients. Qualitative data related to what digital methods the organizations use in contacting their clients was clustered in the following categories: communication platform, workplace platform, social media platforms, webinars, e-mail, telephone, digital documentation and remote customer service. No country related differences were spotted in the usage of the mentioned digital channel categories. Contacting clients by using more digital methods relates directly to the change in consumer behaviour because of the COVID-19 crisis.

As a conclusion we can state that both Romanian and Dutch organizations have adapted their business models to the ongoing COVID-19 crisis by applying digitalization in their value creation and delivery. Both countries have managed to adapt their business models using different digital methods. The frequency and specific digital methods used are in line with existing digitalization levels of Romania and The Netherlands provided by the DESI index.

This shows that digitalization helps organizations to create resilient business models, but with the choice and implementation of applied digital methods depending on the level of digitalization in the organization's country.

A limitation of the study is the size of the sample used, which although sufficiently reliable from a statistical view, may not encompass the organization diversity required to be fully representative of the business environment in the two countries. Another limitation could be the relative low number of COVID-19 related academic papers in order to correlate the obtained results. Finally, as this study was cross-sectional, differences between sectors have not been taken into account.

We believe that future studies are necessary to better understand the impact of COVID-19 pandemic on business models and the use of digitalization in reducing its negative consequences on business models. Relevant further studies could evaluate if the digital changes in both Romania and The Netherlands under COVID-19 have had any repercussions to the ongoing digital development of the two countries using any of DESI dimensions as this might have an uplifting effect for the longer term (i.e. possible increased use of internet across the Romanian population). 


\section{References}

Bouwman, H., de Reuver, M., \& Shahrokh, N. (2017): The impact of digitalization on business models: How IT artefacts, Social Media and Big data forms firms to innovate their business model. 14th International Telecommunications Society (ITS) Asia-Pacific Regional Conference, Kyoto, June 24-27. Calgary: International Telecommunications Society(ITS), (2017).

Bouwman, H., De Vos, H., \& Haaker, T. (2008): Mobile service innovation and business models. Heidelberg: Springer Verlag, (2008).

Butu, A., Bruma, I., Tanasa, L., Rodino, S., Vasiliu, C., Dobos, S., \& Butu, M.: The impact of COVID-19 crisis upon the consumer buying behavior of fresh vegetables directly from local producers. Case study: The quarantined area of Suceava county, Romania. International journal of environmental research and public health., 17, (2020).

Carnevale, J., \& Hatak, I.:Employee adjustment and well-being in the era of COVID-19: Implications for human resource management. Journal of Business Research 116, 183187, (2020).

Chesbrough, H., \& Rosenbloom, R. S.: The role of the business model in capturing value from innovation: evidence from Xerox Corporation's technology spin-off companies. Industrial and Corporate Change, 11, 529-555, (2002).

Chun, H., Diehl, K., \& Maclnnis, D.: Savoring an upcoming experience affects ongoing and remembered consumption enjoyment. Journal of Marketing, 81(3), 96-110, (2017).

De Reuver, M., Bouwman, H., \& Maclnnes, I.: Business models dynamics for start-ups and innovating e-businesses. International Journal of Electronic Commerce, 7(3), 269-286, (2009).

De Vos, H., \& Haaker, T.: The STOF method. In H. Bouwman, H. De Vos, \& T. Haaker, Mobile Service Innovation and business models. Berlin: Springer Verlag, (2008).

El-Sawy, O., \& Pereira, F.: Business Modelling in the dynamic digital space: an ecosystem approach. Heidelberg New York: Springer, (2013).

European Commission : DESI country calculator. Retrieved from Digital Data EU: https://digitalagenda-data.eu/datasets/desi/visualizations, (2020, Nov 14).

European Commission : Digital Economy and Society Index (DESI) 2020. Brussels: European Commission. Retrieved from Digital Economy and Society Index, (2020).

European Commission : Digital Economy and Society Index, Romania. Brussels: European Commission, (2020).

European Commission : Digital Economy and Society Index, The Netherlands. Brussels: European Commission, (2020)

Field, A.: Discovering statistics using SPSS, Third edition. Sage publishing, (2009).

Fletcher, G., \& Griffiths, M.: Digital transformation during a lockdown. International Journal of Information Management, 55, (2020).

Kirk, C., \& Rifkin, L.: I'll trade you diamonds for toilet paper: Consumer reacting, coping and adapting behaviors in the COVID-19 pandemic. Journal of business research, (2020).

Kotler, P; Armstrong, G.: Principles of Marketing Global edition. Pearson, (2015).

Kotler, P; Kartajaya, H; Setiawan, I.: Marketing 3.0: From products to customers to the Human spirit. Singapore: Springer, (2010).

Linder, J., \& Cantrell, S.: Changing Business Models : Surveying the Landscape. Massachusetts: Accenture, Institute for Strategic Change, (2000). 
Lüdeke-Freund, F., Gold, S., \& Bocken, N.: A review and typology of circular economy business model patterns. Journal of Industrial Ecology, 23(1), 36-61, (2019).

McGrath, G.: Business Models: A Discovery Driven Approach. Long Range Planning, 43(2-3), 247-261, (2010).

OECD: Social economy and the COVID-19 crisis: current and future roles. Retrieved from OECD : https://read.oecd-ilibrary.org/view/?ref=135 135367-031kjiq7v4\&title=Social-economyand-the-COVID-19-crisis-current-and-future-roles, (2020, July 30).

OECD: Supporting people and Companies to deal with the COVID-19 virus: Options for an immediate employment and social-policy response. Retrieved from OECD: https://www.oecd.org/coronavirus/policy-responses/supporting-people-and-companies-todeal-with-the-covid-19-virus-options-for-an-immediate-employment-and-social-policyresponse-d33dffe6/, (2020, March 20).

Osterwalder, A., \& Pigneur, Y.: Business Model Generation. John Wiley \& Sons, Inc., (2010).

Poelman, M., Gillebaart, M., Schlinkert, C., Dijkstra, S., Derksen, E., Mensink, F., .de Vet, E.: Eating behavior and food purchases during COVID-19: A cross-sectional study among adults in The Netherlands. Elsevier Health Emergency Collection, (2020).

Rachinger, M., Rauter, R., Muller, C., Vorrader, W., \& Schirgi, E.: Digitalization and its influence on business model innovation. Journal of Manufacturing \& Technology Management, 1143-1160, (2019).

Vorraber, W., Gundhille, B., Rachinger, M., Rauter, R., \& Eva, S.: Towards a better understanding of digitalization and its influence on business model innovation. 2nd International conference on New Business Models (p. 132). Graz: Institute for Systems Science, Innovation and Sustainability research, (2017).

World Bank: What have we learnt? Overview of findings from a survey of ministries of education on national responses to COVID-19. Paris: World bank, (2020).

World Health Organization : Considerations in adjusting public health and social measures in the context of Covid-19. Retrieved from World Health Organization: https://www.who.int/publications/i/item/considerations-in-adjusting-public-health-andsocial-measures-in-the-context-of-covid-19-interim-guidance 